\title{
Isolation and free-radical-scavenging properties of cyanidin 3-O-glycosides from the fruits of Ribes biebersteinii Berl.
}

\author{
ABBAS DELAZAR ${ }^{1}$ \\ LALEH KHODAIE ${ }^{1}$ \\ JALIL AFSHAR ${ }^{1}$ \\ LUTFUN NAHAR ${ }^{2}$ \\ SATYAJIT D. SARKER $3, *$ \\ 1 School of Pharmacy, Drug Applied \\ Research Center, Tabriz University \\ of Medical Sciences, Tabriz, Iran \\ ${ }^{2}$ Drug Discovery and Design Research \\ Division, Department of Pharmacy \\ School of Applied Sciences, University \\ of Wolverhampton, MA Building \\ Wulfruna Street, Wolverhampton \\ WV1 1LY, West Midland, UK \\ ${ }^{3}$ Department of Pharmacy, School \\ of Applied Sciences, University of \\ Wolverhampton, MM Building \\ Molineux Street, Wolverhampton \\ WV1 1SB, West Midland, UK
}

\begin{abstract}
The reversed-phase preparative high performance liquid chromatographic purification of the methanol extract of the fruits of Ribes biebersteinii Berl. (Grossulariaceae) afforded five cyanidin glycosides, 3-O-sambubiosyl-5-O-glucosyl cyanidin (1), cyanidin 3-O-sambubioside (2), cyanidin 3-O-glucoside (3), cyanidin $3-\mathrm{O}-\left(2^{\mathrm{G}}\right.$-xylosyl)-rutinoside (4) and cyanidin 3-O-rutinoside (5). They showed considerable free-radical-scavenging properties in the 2,2-diphenyl-1-picrylhydrazyl (DPPH) assay with the $R C_{50}$ values of $9.29 \times 10^{-6}, 9.33 \times 10^{-6}, 8.31 \times 10^{-6}, 8.96 \times 10^{-6}$ and 9.55 $\times 10^{-6} \mathrm{~mol} \mathrm{~L}^{-1}$, respectively. The structures of these compounds were elucidated by various chemical hydrolyses and spectroscopic means. The total anthocyanin content was $1.9 \mathrm{~g}$ per $100 \mathrm{~g}$ dried fruits on cyanidin 3-glucoside basis.

Keywords: Ribes biebersteinii Berl. (Grossulariaceae), 2,2-diphenyl-1-picrylhydrazyl (DPPH), cyanidin glycoside, free-radical-scavenger
\end{abstract}

Accepted January 21, 2010

The red-violet colour in fruits and vegetables is derived mainly from a class of flavonoids called anthocyanins. To date, more than 300 different anthocyanins have been identified in different plants. There has been an increased interest in natural anthocyanins and anthocyanin containing plants because of their potential health promoting properties and, above all, for their protection against free radicals (1). The Ribes species are known to contain high amounts of anthocyanins. Ribes biebersteinii Berl. (Grossulariaceae), commonly known as 'reddish-black berry', is an Iranian medicinal plant (2-4). The fruits of $R$. biebersteinii are used as food and also in the traditional medicine as a hypotensive agent and as a retina-protectant. No phytochemical or bioactivity studies on $R$. bieber-

\footnotetext{
* Correspondence; e-mail: s.sarker@wlv.ac.uk
} 
A. Delazar et al.: Isolation and free-radical-scavenging properties of cyanidin 3-O-glycosides from the fruits of Ribes biebersteinii Berl., Acta Pharm. 60 (2010) 1-11.

steinii have ever been carried out previously. As part of our on-going studies on Iranian medicinal plants, we now report on the isolation and identification of anthocyanin glycosides from the fruits of $R$. biebersteinii and their potential free-radical-scavenging property in the DPPH assay.

\section{EXPERIMENTAL}

\section{General}

${ }^{1} \mathrm{H}$ NMR spectra were recorded on a Varian FT-400 Unity Plus (400 MHz) spectrometer (USA), HPLC (Shimadzu, LC-8A, Japan) and UV-Visible spectrophotometer (Shimadzu, 2100, Japan) were used. The NMR spectra were recorded in $\mathrm{D}_{2} \mathrm{O}$ (10 \% trifluoroacetic acid, TFA) at $399.866 \mathrm{MHz}$ for ${ }^{1} \mathrm{H}$ NMR and $100.556 \mathrm{MHz}$ for ${ }^{13} \mathrm{C}$ NMR. Chemical shifts $(\delta)$ are given in ppm relative to the internal standard TMS. UV-Visible spectrum of each compound was recorded in $\mathrm{MeOH}$ containing $0.01 \% \mathrm{HCl}$ and after addition of 3 drops of $5 \% \mathrm{AlCl}_{3}$ in anhydrous $\mathrm{MeOH}$ (shift reagent) at $190-700 \mathrm{~nm}$.

\section{TLC plates and chemicals}

Silica gel plate $\left(\mathrm{GF}_{254}\right)$, microcrystalline cellulose plate, $\mathrm{AlCl}_{3}$, methanol, diethyl ether, formic acid, reference sugars, concentrated hydrochloric acid, DPPH, vitamin C and trifluoroacetic acid were purchased from Merck (Germany) and Sigma-Aldrich (Japan), and were of analytical grade. For HPLC analyses, water and $\mathrm{MeOH}$ were of HPLC-grade and were purchased from VWR Internatinal Ltd (UK).

\section{Plant material}

The fruits of Ribes biebersteinii Berl. (Grossulariaceae) were collected from the Arasbaran area of the eastern Azarbaijan province, Iran, during September-October 2002, and a voucher specimen representing this collection was retained in the herbarium of the School of Pharmacy, Tabriz University of Medical Sciences, Tabriz, Iran.

\section{Extraction}

Shed-dried and ground fruits of $R$. biebersteinii Berl. (10 g) were macerated with $\mathrm{MeOH}$ containing $0.01 \% \mathrm{HCl}(100 \mathrm{~mL})$. The extract was refrigerated for $1 \mathrm{~h}$ and filtered through a cellulose paper filter. Extraction was repeated twice, each time by $60 \mathrm{~mL}$ of $0.01 \% \mathrm{HCl}$ in $\mathrm{MeOH}$. Then, the filtered extracts were pooled together and concentrated under vacuum in a rotary evaporator (Büchi, Germany). Diethyl ether was added. Anthocyanins precipitated out due to the decrease in dielectric constant. Subsequently, the precipitate was separated by a centrifuge at $1000 \mathrm{rpm}$ (Beckmann Coulter, USA). This procedure was repeated several times until no precipitation took place in order to get pure anthocyanins. Separated and cleaned precipitate was completely dried under nitrogen gas and stored in the refrigerator. 


\section{Isolation}

The preparative high performance liquid chromatography (HPLC) (Dr Maisch ODS preparative column $10 \mu \mathrm{m}, 250 \mathrm{~mm} \times 20 \mathrm{~mm}$; mobile phase: $0-260 \mathrm{~min}, 0-10 \% \mathrm{~B}$ in A (A $=10 \%$ formic acid in water, $\mathrm{B}=10 \%$ formic acid in $\mathrm{MeOH}$, followed by $10 \% \mathrm{~B}$ in $\mathrm{A}$ for

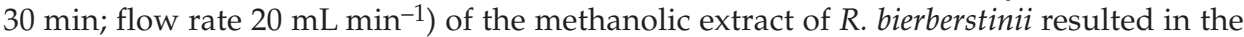
isolation of five cyanidin glycosides, 3-O-sambubiosyl-5-O-glucosyl cyanidin (1, $50.6 \mathrm{mg}$, $\left.t_{\mathrm{R}}=178.0 \mathrm{~min}\right)$, cyanidin 3-O-sambubioside $\left(2,5.1 \mathrm{mg}, t_{\mathrm{R}}=215.0 \mathrm{~min}\right)$, cyanidin 3-O-glucoside $\left(3,10.8 \mathrm{mg}, t_{\mathrm{R}}=226.3 \mathrm{~min}\right)$, cyanidin 3-O-(2G-xylosyl)-rutinoside $(4,9.3 \mathrm{mg}$, $\left.t_{\mathrm{R}}=238.6 \mathrm{~min}\right)$ and cyanidin $3-O$-rutinoside $\left(5,5.7 \mathrm{mg}, t_{\mathrm{R}}=279.1 \mathrm{~min}\right)$.

\section{Acidic hydrolysis}

Purified anthocyanin mixture ( $3 \mathrm{mg}$ ) was dissolved in a minimum amount of acidified $\mathrm{MeOH}\left(3 \mathrm{~mol} \mathrm{~L}^{-1} \mathrm{HCl}\right)$. The test tube was placed in a boiling water bath for $1 \mathrm{~h}$. The cooled solution was divided into two parts and the solvent was evaporated with a rotary-evaporator. One of the solutions was treated with acidic $\mathrm{MeOH}$ for identification of genins and the other with water for identification of glycones by thin layer chromatography (TLC). TLC analyses of genins and glycones were performed using the solvent system butanol/acetic acid/water (4:1:5) (BAW) and microcrystalline cellulose as a stationary phase. Detection of glycones was carried out using aniline-hydrogen phthalate reagent (5).

\section{Alkaline hydrolysis}

Ethanol $(2 \mathrm{~mL})$ was added to $2 \mathrm{mg}$ of purified anthocyanins. The test tube was flushed with nitrogen and capped. The solution was saponified with $10 \mathrm{~mL}, 2 \mathrm{~mol} \mathrm{~L}-1$ $\mathrm{NaOH}$ for $2 \mathrm{~h}$ in the dark at $\mathrm{r}$. t. After neutralization of the solution with $2 \mathrm{~mL}$ of $2 \mathrm{~mol}$ $\mathrm{L}^{-1} \mathrm{HCl}$, it was decanted using diethyl ether $(5 \mathrm{~mL})$. For identification of probable acyls linked to anthocyanin structure, the ether phase was examined. Aqueous phase was used for identification of anthocyanins. The TLC of two phases was carried out using BAW (4:1:5) and F366 microcrystalline cellulose as above (5).

\section{Peroxide hydrolysis}

This procedure is specific for sugars on the C-3 position of cyanidins. Approximately $2 \mathrm{mg}$ of anthocyanin pigment was dissolved in $\mathrm{MeOH}$ and treated dropwise with $3 \%$ peroxide solution until the pigment was bleached. After addition of conc. ammonia solution $(1 \mathrm{~mL})$, the mixture was concentrated, spotted on a microcrystalline cellulose TLC plate together with reference sugar solution and developed for sugars. Chromatography was carried out using BAW (4:1:5) and microcrystalline cellulose. Mono-, di- and tri-glycosides would be removed intact from C-3 and could be identified with appropriate reference sugars (6). 
A. Delazar et al.: Isolation and free-radical-scavenging properties of cyanidin 3-O-glycosides from the fruits of Ribes biebersteinii Berl., Acta Pharm. 60 (2010) 1-11.

\section{Continuous hydrolysis}

Each anthocyanin pigment $(5 \mathrm{mg})$ was dissolved in $20 \mathrm{~mL}$ of $2 \mathrm{~mol} \mathrm{~L}^{-1} \mathrm{HCl}$ in a test tube. The tube was placed in boiling water and sampled at 5, 10, 15, 20, 30, 45 and 60 min, and the samples were chromatographed by TLC using the solvent system BAW and microcrystalline cellulose as above (6).

\section{FAB-MS analysis}

Anthocyanin pigment was dissolved in $\mathrm{MeOH}$ for the Fast Atom Bombardment Mass Spectroscopy (FAB-MS) analysis using a Finnigan MAT95 spectrometer (UK). The instrument response was first optimized by infusing a constant flow $(1-2 \mu \mathrm{L} \mathrm{min}-1)$ of solution. After evaporation of methanol, 1-2 $\mu \mathrm{L}$ glycerol (matrix liquid) was added to the pigment. Elucidation of the structure of pigments was done by fragmentation of the molecular ions in the cell of the mass spectrometer, using xenon flow.

\section{Total anthocyanin content}

Total anthocyanin content of the fruits of $R$. biebersteinii was measured using the $\mathrm{pH}$ differential absorbance method (7). The absorbance of the extract was measured at 510 and $700 \mathrm{~nm}$ in buffers at $\mathrm{pH} 1.0$ (hydrochloric acid/potassium chloride, $0.2 \mathrm{~mol} \mathrm{~L}^{-1}$ ) and 4.5 (acetate acid/sodium acetate, $1 \mathrm{~mol} \mathrm{~L}^{-1}$ ). Anthocyanin content was calculated using a molar extinction coefficient of 29,600 (cyanidin 3-glucoside) and absorbance of $A=$ $\left[\left(A_{510}-A_{700}\right)_{\mathrm{pH} 1.0}-\left(A_{510}-A_{700}\right)_{\mathrm{pH}} 4.5\right]$. Results were expressed as mg cyanidin 3-glucoside equivalents in $100 \mathrm{~g}$ of dried fruits.<smiles>[R20]Cc1cc(O)cc2[o+]c(-c3ccc(O)c(O)c3)c(O[C@@H]3OC([R2])[C@@H](O)[C@H](O)[C@H]3O[R])cc12</smiles>

$\begin{array}{cccc}\text { Compd. } & \mathrm{R} & \mathrm{R}^{\prime} & \mathrm{R}^{\prime \prime} \\ \mathbf{1} & \text { xylosyl } & \mathrm{H} & \text { glucosyl } \\ \mathbf{2} & \text { xylosyl } & \mathrm{H} & \mathrm{H} \\ \mathbf{3} & \mathrm{H} & \mathrm{H} & \mathrm{H} \\ \mathbf{4} & \text { xylosyl } & \text { rhamnosyl } & \mathrm{H} \\ \mathbf{5} & \mathrm{H} & \text { rhamnosyl } & \mathrm{H}\end{array}$

Fig. 1. Structures of cyanidin glycosides isolated from the fruits of Ribes biebresteinii Berl. 
A. Delazar et al.: Isolation and free-radical-scavenging properties of cyanidin 3-O-glycosides from the fruits of Ribes biebersteinii Berl., Acta Pharm. 60 (2010) 1-11.

\section{Free-radical-scavenging activity (DPPH assay)}

The method used by Du et al. (8) was adopted with suitable modifications. The sample solutions $\left(0.8 \mathrm{mg} \mathrm{mL}^{-1}\right)$ were prepared by dissolving each sample in water. These sample solutions were diluted to $0.4,0.2$ and $0.1 \mathrm{mg} \mathrm{mL}^{-1}$, stored in a refrigerator at $4{ }^{\circ} \mathrm{C}$ before testing for radical scavenging activity. In the test protocol of radical scavenging activity, $2.9 \mathrm{~mL}$ of $65 \mathrm{mmol} \mathrm{L}-1 \mathrm{DPPH}$ reagent in methanol/water $(80: 20, V / V)$ was added to $0.1 \mathrm{~mL}$ of sample solution to be tested. After $30 \mathrm{~min}$ of reaction at $25{ }^{\circ} \mathrm{C}$, the absorbance was measured at $515 \mathrm{~nm}$. The radical scavenging activity $R_{\mathrm{S}}$ was expressed as percentage of DPPH radical elimination calculated from absorbance of the sample at reaction time $0 \mathrm{~min}$ and the sample absorbance at $30 \mathrm{~min}$ of the reaction. The experiment was performed in duplicate and average absorption was noted for each concentration. The concentration that caused a $50 \%$ reduction in absorbance $\left(R C_{50}\right)$ was calculated. The same procedure was followed for the positive control, vitamin $C$.

\section{RESULTS AND DISCUSSION}

Various hydrolyses followed by co-TLC analyses $(9,10)$ of the glycone and aglycone portions of purified anthocyanin pigments (1-5) together with reference sugars and cyanidin confirmed the identity of the aglycone as cyanidin in 1-5 and respective glycones, e.g., glucose, xylose and rutinose.

The peroxide hydrolysis of compound 1 indicated the presence of sambubiose at C-3 of cyanidin. The UV-visible spectral analysis $(\mathrm{MeOH}+0.01 \% \mathrm{HCl})$ of $\mathbf{1}$ showed absorption maxima $\left(\lambda_{\max }\right)$ at 524 and $279 \mathrm{~nm}$, which were in agreement with the absorbance pattern of cyanidin 3-O-glycosides (11). The $E_{440} / E_{\mathrm{vis}}\left(E_{440}=\right.$ absorption at $440 \mathrm{~nm}$ and $E_{\text {Vis }}=$ absorption at band $I$ in the visible wavelength, $>500 \mathrm{~nm}$; for example, in compound 1 the band I was at $524 \mathrm{~nm}$ ) ratio $25.8 \%$ also supported the above fact (12). Addition of $5 \% \mathrm{AlCl}_{3}$ reagent to methanolic solution showed approximately a $40-\mathrm{nm}$ bathochromic shift, which demonstrated ortho-di hydroxyl groups on the B-ring of cyanidin (9-12). The FAB-MS spectrum of 1 displayed the pseudomolecular ions $\left[\mathrm{M}^{+}+1\right]$ and $\left[\mathrm{M}^{+}+2\right]$ at $m / z 744$ and 745 , respectively (Table I). The fragment ions at $m / z 611,581$ and 287 corresponded to $\left[\mathrm{M}^{+}\right.$-xylose], $\left[\mathrm{M}^{+}\right.$-glucose] and $\left[\mathrm{M}^{+}\right.$-glucose-sambubiose], respectively. Thus, from the peroxide hydrolysis, and UV-Vis and FAB-MS analyses, it was obvious that the cyanidin aglycone in $\mathbf{1}$ was substituted at C-3 and C-5, the glycone at C-3 was a disaccharide and at $\mathrm{C}-5$ a glucose (13), while compound 1 was 3-O-sambubiosyl-5-O-glucosyl cyanidin. The ${ }^{1} \mathrm{H}$ NMR (Table II) and ${ }^{13} \mathrm{C}$ NMR spectra (Table III) of 1 exhibited signals corresponding to cyanidin aglycone $(14,15)$, sambubiose and glucose. The ${ }^{1} \mathrm{H}$ NMR (Table II) and ${ }^{13} \mathrm{C}$ NMR spectra (Table III) of $\mathbf{1}$ exhibited signals corresponding to cyanidin aglycone $(14,15)$ and $2^{\mathrm{G}}$-glucosylrutinose glycone. In the ${ }^{1} \mathrm{H}$ NMR spectrum, a $1 \mathrm{H}$ singlet at $\delta 8.98 \mathrm{ppm}$ was typical of $\mathrm{H}-4$ of the cyanidin moiety. Similarly, two $1 \mathrm{H}$ doublet at $\delta 8.09(J=2.2 \mathrm{~Hz})$ and $7.95(J=8.9 \mathrm{~Hz}) \mathrm{ppm}$, a $1 \mathrm{H}$ doublets of a doublet at $\delta$ $8.32(J=8.9,2.2 \mathrm{~Hz})$ and two $1 \mathrm{H}$ singlets at $\delta 7.02$ and $6.91 \mathrm{ppm}$ corresponded, respectively, to H-2', H-5', H-6', H-8 and H-6 of cyanidin. The anomeric proton signals for three sugars, two glucoses and a xylose, appeared at $\delta 5.57(1 \mathrm{H}, \mathrm{d}, J=7.8 \mathrm{~Hz}), 5.32(1 \mathrm{H}, \mathrm{d}, J=$ $7.7 \mathrm{~Hz})$ and $4.69(1 \mathrm{H}, \mathrm{d}, J=7.9 \mathrm{~Hz}) \mathrm{ppm}$. The ${ }^{1} \mathrm{H}$ NMR signals corresponding to other 
A. Delazar et al.: Isolation and free-radical-scavenging properties of cyanidin 3-O-glycosides from the fruits of Ribes biebersteinii Berl., Acta Pharm. 60 (2010) 1-11.

Table I. FAB-MS data of compounds 1-5

\begin{tabular}{|c|c|c|c|}
\hline \multirow{2}{*}{$\begin{array}{l}\text { Cyanidin } \\
\text { glycosides }\end{array}$} & \multicolumn{2}{|c|}{ Pseudomolecular ions $(\mathrm{m} / \mathrm{z})$} & \multirow{2}{*}{ Major fragment ions $(\mathrm{m} / \mathrm{z})$} \\
\hline & {$\left[\mathrm{M}^{+}+1\right]$} & {$\left[\mathrm{M}^{+}+2\right]$} & \\
\hline 1 & 744 & 745 & $\begin{array}{c}611\left[\mathrm{M}^{+}-\text {xylose }\right], 581\left[\mathrm{M}^{+}-\text {glucose }\right] \\
287\left[\mathrm{M}^{+}-\text {sambubiose-glucose }\right]\end{array}$ \\
\hline 2 & 582 & 583 & $449\left[\mathrm{M}^{+}\right.$- xylose $], 287\left[\mathrm{M}^{+}\right.$- sambubiose $]$ \\
\hline 3 & 450 & 451 & $287\left[\mathrm{M}^{+}-\right.$glucose $]$ \\
\hline 4 & 728 & 729 & $\begin{array}{c}595\left[\mathrm{M}^{+}-\text {xylose }\right], 581\left[\mathrm{M}^{+}-\text {rhamnose }\right] \\
449[\mathrm{M}+- \text { xylose-rhamnose }] \\
287\left[\mathrm{M}^{+}-\text {xylose }- \text { rhamnose-glucose }\right]\end{array}$ \\
\hline 5 & 596 & 597 & $\begin{array}{c}449\left[\mathrm{M}^{+}-\text {rhamnose }\right] \\
287\left[\mathrm{M}^{+}-\text {rhamnose-glucose }\right]\end{array}$ \\
\hline
\end{tabular}

sugar protons appeared as overlapped peaks within the region of $\delta 3.20-4.30 \mathrm{ppm}$. The ${ }^{13} \mathrm{C}$ NMR spectrum (Table III) of $\mathbf{1}$ displayed all 15 signals corresponding to the cyanidin moiety as well as the carbons of all three sugar moieties $(14,15)$. Thus, compound 1 was identified as 3-O-sambubiosyl-5-O-glucosyl cyanidin.

Like in case of compound $\mathbf{1}$ (discussed above), combined hydrolyses and co-TLC of glycosides 2-5 revealed the presence of cyanidin as the aglycone in these molecules. This fact was further corroborated by the FAB-MS spectra of the glycosides (Table I) where a major fragment ion at $\mathrm{m} / \mathrm{z} 287$ corresponding to the cyanidin moiety was present. Addition of $5 \% \mathrm{AlCl}_{3}$ reagent to methanolic solution (containing $0.01 \% \mathrm{HCl}$ ) of compound 2-5 showed an approximately 40-nm bathochromic shift, which demonstrated the presence of ortho-di hydroxyl groups on the B-ring of cyanidin (9-12). The UV-Vis spectrum $(\mathrm{MeOH}+0.01 \% \mathrm{HCl})$ of 2 showed absorption maxima $\left(\lambda_{\max }\right)$ at 280 and 526 $\mathrm{nm}$, supporting the presence of cyanidin 3-O-glycoside skeleton in 2, similar to that of $\mathbf{1}$. The glycosylation at C-3 was further confirmed by the $E_{440} / E_{\mathrm{Vis}}$ ratio (23\%) (12). The FAB-MS spectrum (Table I) of 2 displayed the pseudomolecular ions $\left[\mathrm{M}^{+}+1\right]$ and $\left[\mathrm{M}^{+}+2\right]$ at $\mathrm{m} / \mathrm{z} 582$ and 583, respectively, which corresponded to the structure of cyanidin 3-O-sambubioside (2). The ${ }^{1} \mathrm{H}$ and ${ }^{13} \mathrm{C}$ NMR spectra (Tables II and III) of 2 were similar to those of 1 except for the fact that the signals corresponding to the second glucose moiety (like in $\mathbf{1}$ ) were absent. Thus, glycoside 2 was identified as cyanidin 3-O-sambubioside.

The UV-Vis spectra $(\mathrm{MeOH}+0.01 \% \mathrm{HCl})$ of glycosides $\mathbf{3}-\mathbf{5}$ also displayed absorption maxima $\left(\lambda_{\max }\right)$ at 281 and 528, 281 and 529, and 282 and $528 \mathrm{~nm}$, respectively, supporting the presence of cyanidin skeleton with glycosylation at C-3. Like compounds 1 and 2, glycosylation at C-3 in 3-5 was supported by the $E_{440} / E_{\mathrm{Vis}}$ ratio, respectively, 23.2, 24.4 and $24.4 \%$ (12). The ${ }^{1} \mathrm{H}$ and ${ }^{13} \mathrm{C}$ NMR spectra (Tables II and III) of $3-5$ established the presence of C-3 glycosylated cyanidin skeleton like in $\mathbf{1}$ and $\mathbf{2}$. In addition to the signals associated with the cyanidin moiety, the ${ }^{1} \mathrm{H}$ and ${ }^{13} \mathrm{C}$ NMR spectra of 3 revealed the presence of a glucose unit, suggesting that compound 3 was cyanidin 3-O-glucoside. The pseudomolecular ions $\left[\mathrm{M}^{+}+1\right]$ and $\left[\mathrm{M}^{+}+2\right]$ at $m / z 450$ and 451 observed in the FAB-MS spectrum of 3 confirmed the identity of the molecule. 
A. Delazar et al.: Isolation and free-radical-scavenging properties of cyanidin 3-O-glycosides from the fruits of Ribes biebersteinii Berl., Acta Pharm. 60 (2010) 1-11.

Table II. ${ }^{1} \mathrm{H}$ NMR data (400 MHz, coupling constant $\mathrm{J}$ in $\mathrm{Hz}$ in parentheses) of cyanidin glycosides 1-5

\begin{tabular}{|c|c|c|c|c|c|}
\hline \multirow{2}{*}{$\begin{array}{l}\text { Po- } \\
\text { si- } \\
\text { tion }\end{array}$} & \multicolumn{5}{|c|}{ Chemical shift $(\delta$, ppm $)$} \\
\hline & 1 & 2 & 3 & 4 & 5 \\
\hline 4 & $8.98 \mathrm{~s}$ & $9.07 \mathrm{~s}$ & $9.08 \mathrm{~s}$ & $9.02 \mathrm{~s}$ & $9.08 \mathrm{~s}$ \\
\hline 6 & $6.91 \mathrm{~s} \mathrm{br}$ & $6.74 \mathrm{~s} \mathrm{br}$ & $6.74 \mathrm{~s} \mathrm{br}$ & $6.87 \mathrm{~s} \mathrm{br}$ & $6.88 \mathrm{~s} \mathrm{br}$ \\
\hline 8 & $7.02 \mathrm{~s} \mathrm{br}$ & $6.97 \mathrm{~s} \mathrm{br}$ & $6.95 \mathrm{~s} \mathrm{br}$ & $7.03 \mathrm{~s} \mathrm{br}$ & $7.08 \mathrm{~s} \mathrm{br}$ \\
\hline $2^{\prime}$ & $8.09 \mathrm{~d}(2.2)$ & $8.12 \mathrm{~d}(2.4)$ & $8.11 \mathrm{~d}(2.0)$ & $8.10 \mathrm{~d}(2.5)$ & $8.16 \mathrm{~d}(2.0)$ \\
\hline $5^{\prime}$ & $7.05 \mathrm{~d}(8.9)$ & $7.15 \mathrm{~d}(8.8)$ & $7.08 \mathrm{~d}(8.4)$ & $7.10 \mathrm{~d}(8.6)$ & $7.31 \mathrm{~d}(8.5)$ \\
\hline \multirow[t]{2}{*}{$6^{\prime}$} & $8.32 \mathrm{dd}(8.9,2.2)$ & $8.31 \mathrm{dd}(8.8,2.4)$ & $8.30 \mathrm{dd}(8.4,2.0)$ & $8.37 \mathrm{dd}(8.6,2.5)$ & $8.53 \mathrm{dd}(8.5,2.0)$ \\
\hline & 3-O-glucose & 3-O-glucose & 3-O-glucose & 3-O-glucose & 3-O-glucose \\
\hline $1^{\prime \prime}$ & $5.57 \mathrm{~d}(7.8)$ & $5.54 \mathrm{~d}(7.8)$ & $5.42 \mathrm{~d}(8.0)$ & $5.71 \mathrm{~d}(7.6)$ & $5.48 \mathrm{~d}(8.0)$ \\
\hline $2^{\prime \prime}$ & $3.96 \mathrm{~m}$ & $4.12 \mathrm{~m}$ & $3.79 \mathrm{~m}$ & $3.98 \mathrm{~m}$ & $3.78 \mathrm{~m}$ \\
\hline $3^{\prime \prime}$ & $3.75 \mathrm{~m}$ & $3.85 \mathrm{~m}$ & $3.59 \mathrm{~m}$ & $3.74 \mathrm{~m}$ & $3.98 \mathrm{~m}$ \\
\hline $4^{\prime \prime}$ & $3.53 \mathrm{~m}$ & $3.64 \mathrm{~m}$ & $3.49 \mathrm{~m}$ & $3.41 \mathrm{~m}$ & $5.53 \mathrm{~m}$ \\
\hline $5^{\prime \prime}$ & $3.87 \mathrm{~m}$ & $3.78 \mathrm{~m}$ & $3.71 \mathrm{~m}$ & $3.69 \mathrm{~m}$ & $3.89 \mathrm{~m}$ \\
\hline \multirow[t]{3}{*}{$6^{\prime \prime}$} & $\begin{array}{l}4.24 \mathrm{dd} \\
(11.9,2.4)\end{array}$ & $\begin{array}{l}4.02 \mathrm{dd} \\
(11.8,2.1)\end{array}$ & $\begin{array}{l}4.11 \mathrm{dd} \\
(12.0,2.5)\end{array}$ & $\begin{array}{l}3.96 \mathrm{br} \mathrm{d} \\
(10.7)\end{array}$ & $\begin{array}{l}4.28 \mathrm{dd} \\
(11.0,2.0)\end{array}$ \\
\hline & $3.93 \mathrm{~m}$ & $3.86 \mathrm{~m}$ & $3.92 \mathrm{~m}$ & $3.47-3.72$ & $4.08 \mathrm{~m}$ \\
\hline & 2"-O-xylose & 2"-O-xylose & & 2"-O-xylose & 6"-O-rhamnose \\
\hline $1^{\prime \prime \prime}$ & $4.69 \mathrm{~d}(7.9)$ & $4.74 \mathrm{~d}(7.6)$ & & $4.70 \mathrm{~d}(7.8)$ & $4.85 \mathrm{~s}$ \\
\hline $2^{\prime \prime \prime}$ & $2.98 \mathrm{~m}$ & $3.24 \mathrm{~m}$ & & $3.08 \mathrm{~m}$ & $3.97 \mathrm{~m}$ \\
\hline $3^{\prime \prime \prime}$ & $3.22 \mathrm{~m}$ & $3.33 \mathrm{~m}$ & & $3.18 \mathrm{~m}$ & $3.93 \mathrm{~m}$ \\
\hline $4^{\prime \prime \prime}$ & $3.36 \mathrm{~m}$ & $3.37 \mathrm{~m}$ & & $3.21-3.94$ & $3.53 \mathrm{~m}$ \\
\hline $5^{\prime \prime \prime}$ & $\begin{array}{l}3.68 \mathrm{~m}, 3.04 \mathrm{t} \\
(11.1)\end{array}$ & $\begin{array}{l}3.71 \mathrm{~m}, 3.07 \mathrm{t} \\
(10.9)\end{array}$ & & $\begin{array}{l}3.21-3.94 \\
3.21-3.94\end{array}$ & $3.75 \mathrm{~m}$ \\
\hline $6^{\prime \prime \prime}$ & & & & & $1.37 \mathrm{~d}(6.0)$ \\
\hline & 5-O-glucose & & & $6^{\prime \prime}$-O-rhamnose & \\
\hline $1^{\prime \prime \prime \prime}$ & $5.32 \mathrm{~d}(7.7)$ & & & $4.65 \mathrm{~s}$ & \\
\hline $2^{\prime \prime \prime \prime}$ & $3.56 \mathrm{~m}$ & & & $3.76 \mathrm{~m}$ & \\
\hline $3^{\prime \prime \prime \prime}$ & $3.34 \mathrm{~m}$ & & & $3.15-3.50$ & \\
\hline $4^{\prime \prime \prime \prime}$ & $3.29 \mathrm{~m}$ & & & $3.15-3.50$ & \\
\hline $5^{\prime \prime \prime \prime}$ & $3.51 \mathrm{~m}$ & & & $3.56 \mathrm{~m}$ & \\
\hline $6^{\prime \prime \prime \prime}$ & $\begin{array}{l}3.62 \mathrm{~m}, 3.74 \mathrm{~d} \\
(10.8)\end{array}$ & & & $1.08 \mathrm{~d}(6.4)$ & \\
\hline
\end{tabular}

Spectra obtained in $\mathrm{CD}_{3} \mathrm{OD}$.

The ${ }^{1} \mathrm{H}$ and ${ }^{13} \mathrm{C}$ NMR spectra (Tables II and III) of 4 and 5 were similar to those of 3 , except that there were additional signals assignable to a xylosyl and a rhamnosyl unit in 4 , and a rhamnosyl unit in 5 . While the pseudomolecular ions $\left[\mathrm{M}^{+}+1\right]$ and $\left[\mathrm{M}^{+}+2\right]$ at $\mathrm{m} / \mathrm{z}$ 728 and 729 observed in the FAB-MS spectrum (Table I) of 4 confirmed the identity of the molecule as cyanidin 3-O-(2G-xylosyl)-rutinoside, those at $\mathrm{m} / \mathrm{z} 596$ and 597 in the 
A. Delazar et al.: Isolation and free-radical-scavenging properties of cyanidin 3-O-glycosides from the fruits of Ribes biebersteinii Berl., Acta Pharm. 60 (2010) 1-11.

Table III. ${ }^{13} \mathrm{C}$ NMR data (100 MHz) of cyanidin glycosides 1-5

\begin{tabular}{|c|c|c|c|c|c|}
\hline \multirow{2}{*}{ Position } & \multicolumn{5}{|c|}{ Chemical shift $(\delta, \mathrm{ppm})$} \\
\hline & 1 & 2 & 3 & 4 & 5 \\
\hline 2 & 163.5 & 164.5 & 162.8 & 161.8 & 163.2 \\
\hline 3 & 144.4 & 144.8 & 144.6 & 143.9 & 144.5 \\
\hline 4 & 134.4 & 136.2 & 135.8 & 134.1 & 135.1 \\
\hline 5 & 161.3 & 159.3 & 159.0 & 158.0 & 158.0 \\
\hline 6 & 104.1 & 102.9 & 102.5 & 102.4 & 102.5 \\
\hline 7 & 169.0 & 170.8 & 169.5 & 168.6 & 169.4 \\
\hline 8 & 96.0 & 95.7 & 94.2 & 94.2 & 94.2 \\
\hline 9 & 157.8 & 157.3 & 158.2 & 157.0 & 157.8 \\
\hline 10 & 112.5 & 113.7 & 112.4 & 112.1 & 112.0 \\
\hline $1^{\prime}$ & 120.1 & 121.6 & 120.1 & 119.8 & 120.0 \\
\hline $2^{\prime}$ & 117.7 & 118.1 & 117.4 & 118.8 & 117.1 \\
\hline $3^{\prime}$ & 146.1 & 148.0 & 146.3 & 146.3 & 146.3 \\
\hline $4^{\prime}$ & 155.8 & 155.3 & 154.8 & 156.1 & 154.9 \\
\hline $5^{\prime}$ & 117.3 & 117.0 & 116.5 & 117.1 & 116.4 \\
\hline \multirow[t]{2}{*}{$6^{\prime}$} & 128.5 & 129.6 & 127.3 & 127.3 & 127.4 \\
\hline & 3-O-glucosyl & 3-O-glucosyl & 3-O-glucosyl & 3-O-glucosyl & 3-O-glucosyl \\
\hline $1^{\prime \prime}$ & 103.0 & 102.7 & 102.8 & 103.1 & 102.5 \\
\hline $2^{\prime \prime}$ & 81.6 & 83.0 & 73.9 & 82.0 & 73.7 \\
\hline $3^{\prime \prime}$ & 77.0 & 77.4 & 77.1 & 77.3 & 76.5 \\
\hline $4^{\prime \prime}$ & 70.1 & 71.7 & 70.1 & 71.2 & 70.1 \\
\hline $5^{\prime \prime}$ & 76.3 & 77.9 & 77.9 & 77.6 & 77.0 \\
\hline \multirow[t]{2}{*}{$6^{\prime \prime}$} & 61.7 & 62.4 & 61.7 & 65.6 & 66.8 \\
\hline & 2"-O-xylosyl & $2^{\prime \prime}-O-x y l o s y l$ & & 2"-O-xylosyl & 6"-O-rhamnosyl \\
\hline $1^{\prime \prime \prime}$ & 104.1 & 105.4 & & 105.0 & 101.1 \\
\hline $2^{\prime \prime \prime}$ & 74.6 & 75.7 & & 75.6 & 70.9 \\
\hline $3^{\prime \prime \prime}$ & 77.0 & 77.7 & & 77.4 & 71.5 \\
\hline $4^{\prime \prime \prime}$ & 70.0 & 70.7 & & 70.1 & 72.9 \\
\hline $5^{\prime \prime \prime}$ & 66.3 & 67.1 & & 66.8 & 68.9 \\
\hline \multirow[t]{2}{*}{$6^{\prime \prime \prime}$} & & & & & 16.9 \\
\hline & 5-O-glucosyl & & & 6"-O-rhamnosyl & \\
\hline $1^{\prime \prime \prime \prime}$ & 102.3 & & & 102.2 & \\
\hline $2^{\prime \prime \prime \prime \prime}$ & 77.8 & & & 70.6 & \\
\hline $3^{\prime \prime \prime \prime \prime}$ & 76.2 & & & 71.6 & \\
\hline $4^{\prime \prime \prime \prime}$ & 74.1 & & & 72.8 & \\
\hline $5^{\prime \prime \prime \prime}$ & 73.4 & & & 68.8 & \\
\hline $6^{\prime \prime \prime \prime}$ & 61.2 & & & 16.5 & \\
\hline
\end{tabular}

Spectra obtained in $\mathrm{CD}_{3} \mathrm{OD}$. 
A. Delazar et al.: Isolation and free-radical-scavenging properties of cyanidin 3-O-glycosides from the fruits of Ribes biebersteinii Berl., Acta Pharm. 60 (2010) 1-11.

Table IV. Free-radical-scavenging activities $\left(\mathrm{RC}_{50}\right)$ of cyanidin glycosides 1-5 compared to ascorbic acid in the DPPH assay

\begin{tabular}{ccc}
\hline \multirow{2}{*}{ Compd. } & \multicolumn{2}{c}{$R C_{50}$} \\
\cline { 2 - 3 } & $\mathrm{mg} \mathrm{mL}^{-1}$ & $\mathrm{~mol} \mathrm{~L}^{-1}$ \\
\hline $\mathbf{1}$ & $6.90 \times 10^{-3}$ & $9.29 \times 10^{-6}$ \\
$\mathbf{2}$ & $5.42 \times 10^{-3}$ & $9.33 \times 10^{-6}$ \\
$\mathbf{3}$ & $3.73 \times 10^{-3}$ & $8.31 \times 10^{-6}$ \\
$\mathbf{4}$ & $6.51 \times 10^{-3}$ & $8.96 \times 10^{-6}$ \\
$\mathbf{5}$ & $5.68 \times 10^{-3}$ & $9.55 \times 10^{-6}$ \\
Ascorbic acid & $3.25 \times 10^{-3}$ & $1.85 \times 10^{-6}$ \\
\hline
\end{tabular}

FAB-MS spectrum of 5 established the identity of this compound as cyanidin 3-O-rutinoside. All spectroscopic data of compounds 1-5 were in agreement with the respective published data $(12,16-22)$.

To the best of our knowledge, this is the first report on the occurrence of cyanidin glycosides 1-5 in the fruits of Ribes biebersteinii Berl. With the exception of compound 1, in all other compounds the glycosylation was limited to position C-3. Anthocyanins occur almost in all Ribes species. However, significant structural variations have been noted among Ribes anthocyanins. Anthocyanins have previously been applied successfully as chemotaxonomic markers for various plant genera $(23,24)$. The anthocyanins $\mathbf{1}-\mathbf{5}$ isolated and identified in the present study might have some chemotaxonomic implications within the genus Ribes.

All cyanidin glycosides 1-5 displayed s high level of free-radical-scavenging activity, comparable to that of the positive control ascorbic acid (vitamin C), in the DPPH assay. The $R C_{50}$ values of these compounds are presented in Table IV. Among the glycosides, cyanidin 3-O-glucoside (3) exhibited the most potent free-radical-scavenging property with a $R C_{50}$ value of $8.31 \times 10^{-6} \mathrm{~mol} \mathrm{~L}^{-1}\left(R C_{50}\right.$ value of the positive control, vitamin $C$ was $1.85 \times 10^{-6} \mathrm{~mol} \mathrm{~L}^{-1}$ ), while the least active was compound $5 R C_{50}=9.55 \times 10^{-6} \mathrm{~mol}$ $\mathrm{L}^{-1}$ ). In general, the free-radical-scavenging activity of compounds 1-5, like other natural phenolic compounds, is a consequence of the phenolic hydroxyl functionalities present in the molecules. The free-radical-scavenging property of anthocyanins is predominantly due to their ability to act as reducing agents, hydrogen donors and singlet oxygen quenchers and, to some extent, could also be due to their metal chelation potential (25).

\section{CONCLUSIONS}

The present study demonstrated that fruits of Ribes biebersteinii Berl. possess high levels of cyanidin glycosides 1-5. The presence of these free-radical-scavengers in the fruits of this plant might explain, at least to some extent, the retina-protecting activity of this plant, which is probably mediated through its capacity for protecting retina from any oxidative damage. 
A. Delazar et al.: Isolation and free-radical-scavenging properties of cyanidin 3-O-glycosides from the fruits of Ribes biebersteinii Berl., Acta Pharm. 60 (2010) 1-11.

\section{REFERENCES}

1. N. Saint-Cricq de Gaulejac, Y. Glories and N. Vivas, Free radical scavenging effect of anthocyanins in red wines, Food Res. Int. 32 (1999) 327-333; DOI: 10.1016/S0963-9969(99)00093-9.

2. A. R. Clapham, T. G. Tutin and E. F. Warburg, Flora of the British Isles, Cambridge University Press, Cambridge, 1962, pp. 110-123, 459-460, 786-787.

3. A. Scharrer and M. Ober, Anthocyanosides in the treatment of retinopathies, Klin. Monatsbl. Augen. 178 (1981) 386-389; DOI: 10.1055/s-2008-1057228.

4. W. E. Glassgen, R. Hofmann, M. Emmerling, G. D. Neumann and H. U. Seitz, Structure elucidation of saccharides in anthocyanins and flavonols by means of methylation analysis and gas-chromatography, J. Chromatogr. 598 (1992) 81-87; DOI: 10.1016/0021-9673(92)85117-C.

5. L. Longo, A. Scardino, G. Vasapollo and F. Blando, Anthocyanins from Eugenia myrtifolia Sims, Innov. Food Emerging Technol. 8 (2007) 329-332; DOI: 10.1016/j.ifset.2007.03.023.

6. P. Markakis, Anthocyanins as Food Colors, Academic Press, 1982, pp. 190.

7. G. E. Pantelidis, M. Vasilakakis, G. A. Manganaris and G. R. Diamantidis, Antioxidant capacity, phenol, anthocyanin and ascorbic acid contents in raspberries, blackberries, red currants, gooseberries and Cornelian cherries, Food Chem. 102 (2007) 777-783; DOI: 10.1016/j.foodchem. 2006.06.021.

8. Q. Du, J. Zheng and Y. Xu, Composition of anthocyanins in mulberry and their antioxidant activity, J. Food Composition Anal. 21 (2008) 390-395; DOI: 10.1016/j.jfca.2008.02.007.

9. J. B. Harborne, Phytochemical Methods, Chapman and Hall, London 1988, pp. 46-55, 61-68.

10. J. B. Harborne, Comparative Biochemistry of the Flavonoids, Academic Press, New York 1967, pp. $1-36$.

11. D. Strack and V. Wray, Methods in Plant Biochemistry (Ed. J. B. Harborne), Academic Press, London 1989, Vol. 1, pp. 325-356.

12. J. B. Harborne, Spectral methods of characterizing anthocyanins, Biochem. J. 70 (1958) 22-28.

13. N. Saito, C. F. Timberlake, O. G. Tucknott and I. A. S. Lewis, Fast atom bombardment mass-spectroscopy of the anthocyanins violanin and platconin, Photochem. 22 (1983) 1007-1009; DOI: 10.1016/0031-9422(83)85043-2.

14. D. Strack and V. Wray, The Anthocyanin, in Flavonoids Advances in Research Since 1986 (Ed. J. B. Harborne), Chapman and Hall, London 1994, pp. 1-22.

15. D. Strack, V. Wray, W. Metzger and W. Grosse, Two anthocyanins acylated with gallic acid from the leaves of Victoria amazonica, Phytochem. 31 (1992) 989-991; DOI: 10.1016/0031-9422(92) 80054-I.

16. F. Tatsuzawa, N. Saito, K. Shinoda, A. Shigihara and T. Honda, Acylated cyanidin 3-sambubioside-5-glucosides in three garden plants of the Cruciferae, Phytochem. 67 (2006) 1287-1295; DOI: 10.1016/j.phytochem.2006.05.001.

17. N. Saito, F. Tatsuzawa, E. Suenaga, K. Toki, K. Shinoda, A. Shigihara and T. Honda, Tetra-acylated cyanidin 3-sophoroside-5-glucosides from the flowers of Iberis umbellata L. (Cruciferae), Phytochem. 69 (2008) 3139-3150; DOI: 10.1016/j.phytochem.2008.04.010.

18. F. Tatsuzawa, Y. Mikanagi, N. Saito, K. Shinoda, A. Shigihara and T. Honda, Cyanidin glycosides in flowers of genus Corydalis (Fumariaceae), Biochem. Syst. Ecol. 33 (2005) 789-798; DOI: 10.1016/j.bse.2004.12.021.

19. N. Saito, F. Tatsuzawa, A. Nishiyama, M. Yokoi, A. Shigihara and T. Honda, Acylated cyaniding 3-sambubioside-5-glucosides in Matthiola incana, Phytochem. 38 (1995) 1027-1032; DOI: 10.1016/ 0031-9422(94)00659-H.

20. K. Takeda, D. Fischer and H. Grisebach, Anthocyanin composition of Sinapis alba, light induction of enzymes and biosynthesis, Phytochem. 27 (1988) 1351-1353; DOI: 10.1016/0031-9422(88) 80192-4. 
A. Delazar et al.: Isolation and free-radical-scavenging properties of cyanidin 3-O-glycosides from the fruits of Ribes biebersteinii Berl., Acta Pharm. 60 (2010) 1-11.

21. J-P. Goiffon, P. P. Mouly and E. M. Gaydou, Anthocyanic pigment determination in red fruit juices, concentrated juices and syrups using liquid chromatography, Anal. Chim. Acta 382 (1999) 39-50; DOI: 10.1016/S0003-2670(98)00756-9.

22. A. Castañeda-Ovando, M. D. Pacheco-Hernández, M. E. Páez-Hernández, J. A. Rodríguez and C. A. Galán-Vidal, Chemical studies of anthocyanins: A review, Food Chem. 113 (2009) 859-871; DOI: 10.1016/j.foodchem.2008.09.001.

23. C. A. Williams, J. B. Harborne and N. L. Demenezis, The utility of leaf flavonoids as taxonomic markers in the subfamily and generic classification of the Velloziaceae, Biochem. Syst. Ecol. 19 (1991) 483-495; DOI: 10.1016/0305-1978(91)90069-C.

24. B. E. Vanwyk and P. J. D. Winter, Chemotaxonomic value of anthocyanins in Podalyria and Virgilia (tribe Podalyrieae, Fabaceae), Biochem. Syst. Ecol. 22 (1994) 813-818; DOI: 10.1016/0305- 1978 (94)90085-X.

25. Y. Kumarasamy, M. Byres, P. J. Cox, A. Delazar, M. Jaspars, L. Nahar, M. Shoeb and S. D. Sarker, Isolation, structure elucidation and biological activity of flavone C-glycosides from the seeds of Alliaria petiolata, Chem. Nat. Compds. 40 (2004) 122-128; DOI: 10.1023/B:CONC.0000033926.72396.41.

\section{$S A \check{Z} E T A K$}

\section{Izolacija i sposobnost hvatanja slobodnih radikala cijanidin 3-O-glikozida iz plodova Ribes biebersteinii Berl.}

ABBAS DELAZAR, LALEH KHODAIE, JALIL AFSHAR, LUTFUN NAHAR i SATYAJIT D. SARKER

Pet cijanidin glikozida, 3-O-sambubiozil-5-O-glukozil cijanidin (1), cijanidin 3-O-sambubiozid (2), cijanidin 3-O-glukozid (3), cijanidin 3-O-(2G-ksilozil)-rutinozid (4) i cijanidin 3-O-rutinosid (5) izolirani su iz metanolnog ekstrakta plodova Ribes biebersteinii Berl. (Grossulariaceae) koristeći reverzno-faznu preparativnu tekućinsku kromatografiju visoke učinkovitosti. Cijanidin glikozidi pokazali su sposobnost hvatanja slobodnih radikala u pokusu s 2,2-difenil-1-pikrilhidrazilom (DPPH). Dobivene su sljedeće $R C_{50}$ vrijednosti: $9,29 \times 10^{-6}, 9,33 \times 10^{-6}, 8,31 \times 10^{-6}, 8,96 \times 10^{-6}$, odnosno 9,55 $\times 10^{-6} \mathrm{~mol} \mathrm{~L}^{-1}$. Strukture glikozida određene su kemijskom hidrolizom i spektroskopijom masa. Ukupni sadržaj antocijanina bio je 1,9 g na $100 \mathrm{~g}$ suhih plodova preračunato na cijanidin 3-glukozid.

Ključne riječi: Ribes biebersteinii Berl. (Grossulariaceae), 2,2-difenil-1-pikrilhidrazil (DPPH), cijanidin glikozid, hvatač slobodnih radikala

School of Pharmacy, Drug Applied Research Center, Tabriz University of Medical Sciences, Tabriz, Iran

Drug Discovery and Design Research Division, Department of Pharmacy, School of Applied Sciences University of Wolverhampton, Wolverhampton WV1 1LY, West Midland, UK

Department of Pharmacy, School of Applied Sciences, University of Wolverhampton, Wolverhampton WV1 1SB, West Midland, UK 